broad outline of the available information, part three on nucleocytoplasmic relations is unsatisfactory. It contains one chapter on prokaryotes which could have been considered earlier, one on nuclear and cytoplasmic controls, and finally rushes through molecular cytology, synthesis of DNA, RNA and protein. The material in this last chapter could also have been incorporated in the previous parts. The chapter on nuclear and cytoplasmic controls suffers from a poor selection of material with a brief mention of the work of Briggs and King on nuclear transplantation in Amphibia and no mention of the considerable contribution of Gurdon. Neither is there any indication of the volume of information arising from the study of cell hybrids. This part of the book has certainly not been brought up to date.

The book is not without errors and contains such statements as "With the exception of hemogloblin-mRNA, however, most messenger RNA's are unstable and short. lived". The latter would be challenged by many workers including those using Acetabularia, which is quoted earlier in the book as an example where RNA is known to be important in morphogenesis!

Although suitable for introductory undergraduate courses, I feel there are other texts available at the price. SHIRLEY E. HAWKINS

\section{BIRD HAUNTS IN EUROPE}

Where to watch Birds in Britain and Europe

By John Gooders. In collaboration with Jeremy Brock. Pp. 299+ 25 plates. (Deutsch: London, April 1970). 45s. ThIs is a useful guidebook for the field ornithologist or bird watcher. It follows a similar one, by the same author, restricted to Britain. This one covers twentyseven European countries; these include Britain, in perspective. The Soviet Union is not included, and information about Albania and the German Democratic Republic is inevitably almost nil. Surprisingly, there is no separate entry for Gibraltar, which is mentioned under the heading "Spain: Southern Andalucia".

The arrangement is alphabetical by countries, and within countries by places; and there is also an index to the latter. There is a key map for each country, and a certain amount of general information about ornithological sociecies, institutes, and textbooks. For each place there is a general account of the terrain, an indication of the specially interesting species to be seen at different seasons, information about how to get there and where to stay, and often a sketch map of the area.

All this conveniently presented information, collected with the help of experts in or on the several countries, will be invaluable to anybody planning either a birdwatching holiday or a visit for more serious study. One can even dip pleasurably into the book simply to remind oneself or to learn about bird-haunts of outstanding inter. est, whether the teeming wetlands of the Camargue, the migration convergence of the Falsterbo peninsula, or the crowded bird rocks of Shetland. And, as the preface says, "most have never heard of the Biebrzanske marshes or the Obredska Bara". A. Landsborough Thomson

\section{ECONOMIC PESTS}

Pests and Diseases of Tropical Crops and Their Control By G. Fröhlich and W. Rodewald. Translated by H. Liebscher and F. Koehler. Pp. ix $+371+55$ plates. (Pergamon: Oxford, London and Now York, 1970.) 140s.

THzs is an English translation from the German edition, published by Karl-Marx University, Leipzig, in 1963, and it suffers a little from the delay. The translation itself is somewhat patchy in quality and most of it shows evidence of having being done by Germans with a good knowledge of English but nevertheless not by people having English as a mother tongue. There is no doubt that revision by a British (or American) editor would greatly have improved the flow and impact of this book.

To include both the chief pests and diseases of tropical crops in one volume is a formidable task and necessarily leads to much compression and to what seem, to Western eyes at least, as errors and omissions. Possibly this is because the Communist bloc of countries have not accepted certain Western revisions of nomenclature and because the tropics the authors have in mind are more those of the East than the West. Examples of such differences are numerous; to mention two, in the coffee section the berry borer is still referred to as Stephenoderes hampei Ferr. rather than the older Hypothenemus hampei (Ferr. 1867) now accepted. One must admit that $S$. hampei is the name mostly found in economic literature, so that this is not a serious error. On the other hand, the coffee berry disease, now causing so much trouble in Africa, is not referred to as such at all, and the berry damage is only mentioned under "Anthracnose", a serious omission because it is the chief problem of African coffee today.

In the sugar section the Diatraea borers, causing severe losses in all sugar areas in America, are dismissed in a section on Proceras sacchariphagus Boyer as "only locally occurring". We now call this pest Chilo sacchariphagus and spell the author "Bojer". Such discrepancies occur throughout.

Suggested control measures are condensed to the essentials and, surprisingly enough, are mostly chemical in nature. The work ends with a number of "surveys", really appendixes on the use of herbicides, and with summaries of the pests of stored products, timber, in public health and on animals, with brief methods of control.

The book is lavishly illustrated in colour and black-andwhite, the former being of that particular German school of illustration, vivid and clear, but not particularly lifelike. Provided the student realizes that in nature the eyespot of coffee, for instance, will not be so red and well defined, the illustrations will probably be the best feature of this work, leading to easy identification and a summary of, mostly chemical, methods of control. It is to be hoped, however, that students will model neither their English nor their scientific nomenclature on this volume.

GEORGE ORDISH

\section{SPORE REMAINS}

\section{Aspects of Palynology}

Edited by Robert H. Tschudy and Richard A. Scott. Pp. vii +510. (Wiley (Interscience): New York and London, March 1970.) 235s.

Thrs book is a compendium of eighteen chapters contributed by well known authorities from the United States and Britain. The initial chapters are concerned with general topies including the palynological representatives of the plant kingdom, systematics and nomenclature, sedimentation of palynomorphs, sampling, and geological applications. This covers a wide field, but for accounts of general morphology and terminology and for techniques of preparation one is referred to other books.

Nine chapters follow dealing with the palynomorphs from successive geological periods ranging from the Precambrian to the Pleistocene. Each chapter discusses the main types of palynomorphs oceurring and their distribution in time and space. The Precambrian and Lower Palacozoic chapters are concerned with various kinds of algal remains; those that follow deal largely with spores and pollen from higher plants. A final chapter briefly reviews the nature and distribution of fossil dinoflagellates and chitinozoa. 